\title{
Cytological Studies in Some North Indian Scrophulariaceae
}

\author{
S. P. Vii and S. K. Kashyap \\ Botany Department, Panjab University, Chandigarh 160014, India
}

Received March 25, 1975

Worldwide in distribution, the Scrophulariaceae (220 genera and 3,000 species, cf. Willis 1973), is well known for its ornamental and medicinal values. Cytological data is available for only $16 \%$ of the described species (Fedorov 1969, Moore 1973). Of a sizeable number of Indian members ( 275 species in 54 genera; cf. Hooker 1885), 59 species belonging to 31 genera are North Indian in distribution. The present communication deals with the cytological aspects of some of these.

\section{Material and methods}

The material was collected in nature in the North Indian plains and hills within an altitude of $300 \mathrm{~m}-2,200 \mathrm{~m}$. The source of the taxa investigated is given in Table 1.

Cytological studies were carried out in the pollen mother cells, for which purpose, the young flower buds were fixed for 24 hours in Carnoy's fluid and stored in $70 \%$ alcohol until use. The anthers were squashed in $1 \%$ acetocarmine containing traces of iron-acetate. Pollen grain fertility was judged by their stainability with glycero-carmine.

The photomicrographs and the camera lucida drawings are at a uniform magnification of $\times 1510$ except where otherwise mentioned. The voucher specimens have been deposited in the Herbarium of Panjab University, Botany Department, Chandigarh.

\section{Results and discussion}

Cytological studies were made in 14 taxa belonging to 10 genera (Table 1). Normal bivalent formation and their subsequent segregation leading to $100 \%$ pollen fertility was characteristics of all the taxa except where otherwise mentioned. Some of the other cytological features in these are discussed below.

\section{Verbascum L.}

Two investigated species $V$. celsioides Benth. and the morphologically variable $V$. thapsus $\mathrm{L}$. uniformly revealed $\mathrm{n}=18$ (Figs. 1, 2). Both these species were characterised by unequal sized bivalents. Some of the similar sized bivalents were secondarily associated, probably indicating chromosomal homologies. Further meiotic course was normal.

$V$. celsioides was cytologically uninvestigated earlier, whereas, $V$. thapsus is in conformity with the earlier cytological records (Mulligan 1961, Packer 1964, Gadella 
Table 1.

\begin{tabular}{|c|c|c|c|c|}
\hline Species worked out & Voucher no. & Locality & $\begin{array}{l}\text { Chromosome } \\
\text { number }\end{array}$ & $\begin{array}{l}\text { Level of } \\
\text { ploidy }\end{array}$ \\
\hline \multicolumn{5}{|l|}{ Tribe: Verbasceae } \\
\hline Verbascum thapsus L. & 5001 & Kasauli, 2,000 m & $\mathrm{n}=18$ & $4 x$ \\
\hline V. celsioides Benth. & 5014 & $\begin{array}{l}\text { Mandi, } \\
1,000-1,500 \mathrm{~m}\end{array}$ & $\mathrm{n}=18$ & $4 \mathrm{x}$ \\
\hline \multicolumn{5}{|l|}{ Tribe: Antirrhineae } \\
\hline Kickxia ramosissima Janchen & 5002 & $\begin{array}{l}\text { Pinjore, Mugal } \\
\text { Garden, } 300 \mathrm{~m}\end{array}$ & $\mathrm{n}=9$ & $2 \mathrm{x}$ \\
\hline Antirhinum orontium $\mathrm{L}$. & 5004 & $\begin{array}{l}\text { Chandigarh, } \\
280 \mathrm{~m}\end{array}$ & $\mathrm{n}=8$ & $2 x$ \\
\hline A. majus Linn. & 5003 & $\begin{array}{l}\text { P.U. Bot. } \\
\text { Garden, } 280 \mathrm{~m}\end{array}$ & $\mathrm{n}=8$ & $2 \mathrm{x}$ \\
\hline \multicolumn{5}{|l|}{ Tribe: Gratioleae } \\
\hline Mazus rugosus Lour. & 5005 & $\begin{array}{l}\text { Chandigarh, } \\
280 \mathrm{~m}\end{array}$ & $\mathrm{n}=20$ & $4 \mathrm{x}$ \\
\hline $\begin{array}{l}\text { Lindenbergia urticaefolia } \\
\text { Link and Otto. }\end{array}$ & 5006 & $\begin{array}{l}\text { Mussoorie, } \\
1974 \mathrm{~m}\end{array}$ & $\mathrm{n}=25$ & $2 \mathrm{x}_{2} ?$ \\
\hline Torenia cordifolia $\mathrm{Roxb}$ & 5007 & 一do- & $\mathrm{n}=16$ & $4 x$ \\
\hline Vandellia crustacea Benth. & 5013 & Mandi, $1,500 \mathrm{~m}$ & $\mathrm{n}=7$ & $2 \mathrm{x}$ \\
\hline$V$. crustacea Benth. & 5012 & Chandigarh, $280 \mathrm{~m}$ & $\mathrm{n}=14$ & $4 x$ \\
\hline \multicolumn{5}{|l|}{ Tribe: Digitaleae } \\
\hline Veronica anagallis $\mathrm{L}$. & 5008 & Surajpur, $300 \mathrm{~m}$ & $\mathrm{n}=27$ & $6 x$ \\
\hline$V$. agrestis $\mathrm{L}$. & 5009 & Kasauli, 2,000 m & $\mathrm{n}=14$ & $4 x$ \\
\hline \multicolumn{5}{|l|}{ Tribe: Gerardieae } \\
\hline Striga euphrasioides Benth. & 5010 & Chandigarh $280 \mathrm{~m}$ & $\mathrm{n}=20$ & $4 \mathrm{x}$ \\
\hline Centranthera hispida R.Br. & 5011 & Mandi, $1,000 \mathrm{~m}$ & $\mathrm{n}=15$ & $2 \mathrm{x}$ \\
\hline
\end{tabular}

and Kliphuis 1966, Verma and Dhillon 1967, Gill 1971). Håkansson (1926) reported $2 \mathrm{n}=34$ and 36 for this species. Darlington and Wylie (1955) suggested $\mathrm{x}=15,16$ and 18 for Verbascum. Perusal of the literature reveals that V. adrianopolitanum and $V$. glanduligerum both with $2 n=24$ (Boryana Stefanova 1974) represent the lowest chromosome number for the genus. The basic nature of this number cannot be authentically supported since the meiotic hebaviour is not known in these species. On the other hand the predominant occurrence of the chromosome numbers $2 \mathrm{n}=24,32,40,48,64$ (cf. Fedorov 1969, Moore 1973) is tempting enough to consider $\mathrm{x}=8$ as basic for Verbascum. Other chromosome numbers $(2 \mathrm{n}=26,28,30,34,66$; Fedorov, 1.c.; Moore, 1.c.) reported for the genus may have either originated as a consequence of aneuploid loss or gain at different ploidy levels on $\mathrm{x}=8$ or represent different basic sets. Thus both the presently investigated $V$. celsioides and $V$. thapsus showing $\mathrm{n}=18$ might be tetraploids on $\mathrm{x}=9$ or hypertetraploids on $x=8$. It is of interest to note that $V$. phoeniceum exists as two cytotypes with $2 \mathrm{n}=32$ and 36 (cf. Fedorov, 1.c.; Moore, 1.c.) indicating thereby,

Figs. 1-15. 1, Verbascum thapsus, $\mathrm{n}=18$, note secondary associations of similar sized bivalents. 2, V. celsioides, $\mathrm{n}=18.3$, Kickxia ramosissima, 9 bivalents and a nucleolus at diakinesis. 4, Antirrhinum orontium, $\mathrm{n}=8$ at diakinesis. 5-7. A. majus. 5, diakinesis showing 8 bivalents and a nucleolus. 6, two IV and Four II at M-I. 7, A-I showing laggard. 8, Veronica anagallis, $\mathrm{n}=27$ at diakinesis. 9, V. agrestis, $\mathrm{n}=14$ at late M-I. 10, Mazus rugosus, diakinesis showing 


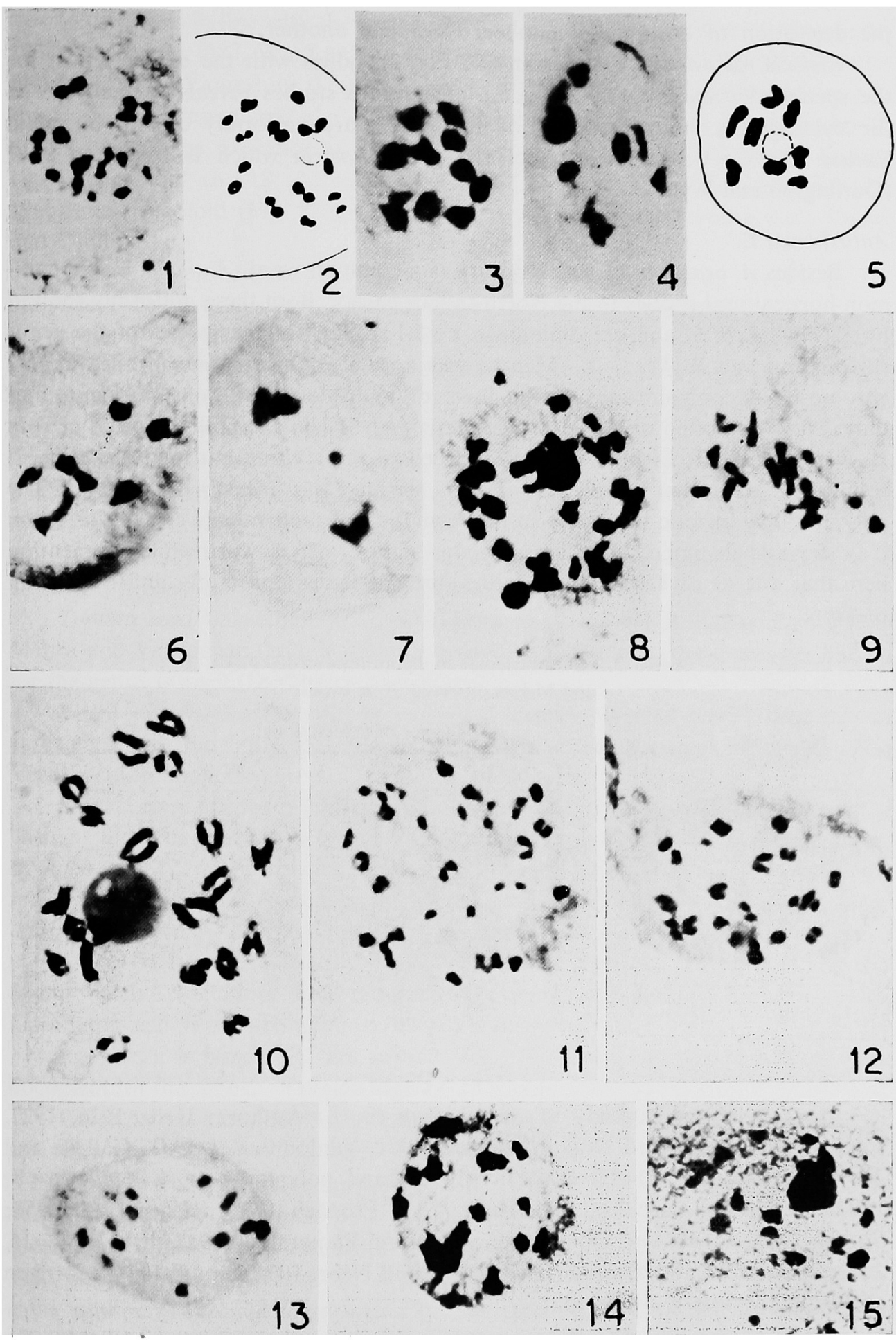

$\mathrm{n}=20$. 11, Lindenbergia, urticaefolia, $\mathrm{n}=25$ at M-I. 12, Striga euphrasioides, M-I with 20 bivalents. 13-14. Vandellia crustacea. 13, cytomorphotype 'A' showing $\mathrm{n}=7$. 14, cytomorphotype ' $B$ ' with $\mathrm{n}=14$. 15 , Centranthera hispida, $\mathrm{n}=15$ at diakinesis. 
the derivation of both these numbers from one another.

Kickxia ramosissima Janchen ( $\mathrm{n}=9$; Fig. 3), tallies with the earlier report for the species (Verma and Dhillon, 1.c.). Literature studies reveals that all the so far cytologically known species of the genus, are uniformly diploid on $x=9$. Earlier Kickxia was treated under the genus Linaria which is based on $\mathrm{x}=7$ (Darlington and Wylie, 1.c.).

Antirrhinum L.

Besides $A$. orontium L. which occurs as a common weed, $A$. majus $\mathrm{L}$. is a common horticultural species in the North-Indian parts. Both these uniformly showed $\mathrm{n}=8$ (Figs. $4,5,6$ ) and are diploid on $\mathrm{x}=8$ like most of the species of the genus (Darlington and Wylie, 1.c.). Meiosis was normal in A. orontium, while variable chromosomal configurations in the form of multiple associations, bivalents and univalents were often observed at diakinesis and M-I in the pollen mother cells in A. majus (Table 2; Figs. 5, 6). In such cells lagging chromatin material (Fig. 7) resulted in abnormal anaphases. Pollen sterility was measured at $40 \%$. The polyploid like meiotic behaviour in the formation of multivalents etc. in this taxon (2x) suggests its interchange heterozygous nature. It is worthwhile to mention here that due to its horticultural values, the species is, constantly under selection pressure.

Table 2. Chromosomal configurations at diakinesis and $\mathrm{M}-\mathrm{I}$ as observed in $A$. majus

\begin{tabular}{|c|c|c|c|c|c|c|c|c|}
\hline \multirow{2}{*}{$\begin{array}{l}\text { No. of cells } \\
\text { studied }\end{array}$} & \multicolumn{8}{|c|}{ Types of associations } \\
\hline & I & II & III & IV & $\mathrm{V}$ & VI & VII & VIII \\
\hline 2 & $x$ & 2 & $x$ & 1 & $x$ & $x$ & $x$ & 1 \\
\hline 2 & $x$ & 4 & $x$ & 2 & $x$ & $x$ & $x$ & $x$ \\
\hline 1 & $x$ & 5 & $x$ & $x$ & $x$ & 1 & $x$ & $x$ \\
\hline 1 & 1 & 6 & 1 & $x$ & $x$ & $x$ & $x$ & $x$ \\
\hline 2 & $x$ & 2 & $x$ & $x$ & $x$ & 2 & $x$ & $x$ \\
\hline 1 & $x$ & 6 & $x$ & 1 & $x$ & $x$ & $x$ & $x$ \\
\hline 1 & $x$ & 2 & $x$ & 3 & $x$ & $x$ & $x$ & $x$ \\
\hline 2 & 1 & 3 & 1 & $x$ & $x$ & 1 & $x$ & $x$ \\
\hline 8 & $x$ & 8 & $x$ & $x$ & $x$ & $x$ & $x$ & $x$ \\
\hline 20 & & & & & & & & \\
\hline
\end{tabular}

Intra-specific aneuploidy in A. orontium ( $\mathrm{n}=8$ : Authors; Heitz 1926, 1927, Larsen 1967, Verma and Dhillon 1.c.; Gill 1971, Vanloon et al. 1971, Gadella and Kliphuis 1971, $\mathrm{n}=7$ : Sobti and Singh 1968) and polyploidy in A. majus $(\mathrm{n}=8$; Authors; 2n=16: Tischler 1920, Heitz 1927, Propach 1935, Rieger 1957, 1958; Stubbe 1966, Verma and Dhillon, 1.c.; Bose and Panigrahi 1969, Gill 1971, $\mathrm{n}=16$, 2n=32: Bamford and Winkles 1941, Ruttle and Nebel 1934, Straub 1941, Morrison and Rajhathy 1960), is evident.

\section{Veronica L.}

Two species, $V$. anagallis $\mathrm{L}$. and $V$. agrestis $\mathrm{L}$. were studied from the polybasic genus Veronica $\left(\mathrm{x}=7,8,9 ; \mathrm{x}_{2}=13,17,26\right.$; Darlington and Wylie 1.c.). V. agrestis 
( $n=14$, Fig. 9) is in line with the earlier identical findings for the species (Rohweder 1937, Yamashita 1937, Wulff 1937, Lehmann et al. 1954, Fischer 1969) and is tetraploid on $x=7$. Yamashita (1.c.) also recorded a diploid cytotype $(2 n=14)$ in this species. The present and the earlier available cytological data for $V$. anagallis points towards its existence at different ploidy levels, i.e. diploid $(n=9$ : Fischer 1969), tetraploid ( $n=18,2 n=36$ : Löve and Löve 1956, Khoshoo and Khushu 1966) and hexaploid (Fig. 8, $\mathrm{n}=27$ : Authors; Khoshoo and Khushu, 1.c.; Verma and Dhillon, 1.c.).

Mazus rugosus Lour. The morphologically variable species, grows in the moist and shady places in the North Indian planes and Himalayan ranges. All the presently studied morphologically variable taxa uniformly revealed $\mathrm{n}=20$ (Fig. 10) in line with the earlier records for the species (Verma and Dhillon, 1.c.). Discordant chromosome numbers $2 \mathrm{n}=24,38,40$ and 104 (cf. Fedorov, 1.c., Moore, 1.c.) make it difficult to ascertain the basic set for Mazus.

Lindenbergia urticaefolia Link and Otto. $(\mathrm{n}=25$, Fig. 11) confirms the previous records for the species (Mehra and Vasudevan 1972). Though $\mathrm{n}=10$ is the lowest gametic number known in Lindenbergia $(\mathrm{n}=10,14,25 \mathrm{cf}$. Mehra and Vasudevan, 1.c.), $\mathrm{n}=25$ in L. urticaefolia with normal meiotic sequence is suggestive of either a low basic set $(x=5$ ? ) or its secondary origin.

Torenia cordifolia Roxb. $(\mathrm{n}=16)$ in accordance with the earlier findings by Mehra and Vasudevan (1.c.), is tetraploid on $x=8$. The other base number known for the genus is $x=9$ (Darlington and Wylie 1.c.).

Striga euphrasioides Benth. Cytological studies revealed $n=20$ (Fig. 12) in agreement with the previous reports for this species (Kumar and Abraham 1941, Verma and Dhillon, l.c.).

Kumar and Abraham (1.c.) suggested $x=8$ for Striga $(n=20,2 n=40)$ on the basis of the occurrence of secondary associations in $S$. densiflora, S. euphrasioides, $S$. lutea and $S$. orobanchoides, whereas, Darlington and Wylie (1.c.) considered $\mathrm{x}=10$ for the genus. According to Mehra and Vij (1972), the complete reliance upon the secondary associations which generally vary from cell to cell in most of the cases is not justified for the deduction of base number. In light of the fact that no such associations were observed in the presently studied $S$. euphrasioides, Darlington and Wylie's contention $(x=10)$ is supported.

Centranthera hispida $\mathrm{R}$. Br. ( $\mathrm{n}=15$, Fig. 15) represents the first cytological document for the genus. Though high $\mathrm{x}=15$ may be taken as basic for Centranthera.

Vandellia crustacea Benth. A common weed met throughout the Indian plains and hills, ascending upto $1,200 \mathrm{~m}$. Flowers: October-November.

A number of collections made from different localities in the area under survey and conforming to the broad description of the species as given by Hooker (l.c.), revealed morphological variations, both in the vegetative and floral characters. Two morphotypes, "A" and "B" (Figs. 16, 17, 18) and differing in their chromosome numbers were distinguished. The morphotype " $A$ " was common in the hills (Mandi, 1,500 m.) and rarely descended below $500 \mathrm{~m}$. It was diploid $(\mathrm{n}=7$ ). The morphotype " $\mathrm{B}$ " was very common in the plain country and was never observed ascending beyond $500 \mathrm{~m}$. It was tetraploid $(n=14)$. Both the cytomorpho- 

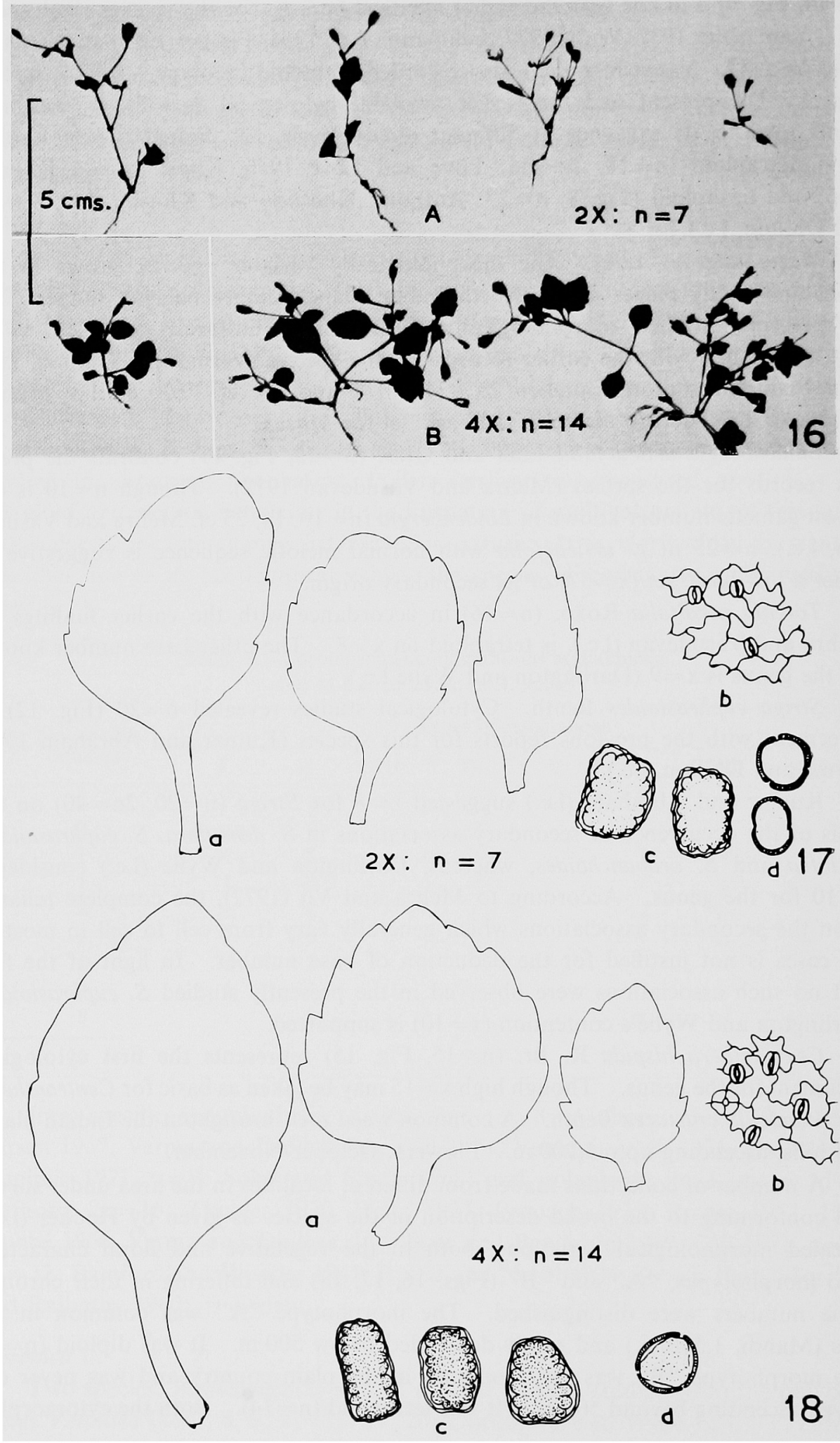
types dwelled along the water channels and/in moist situations.

\section{Morphology}

The polyploidy, in general was associated with the quantitative increase in the morphological features.

Plant size and branching pattern: The plants ranged in size between 3.00 $5.00 \mathrm{cms}$. in diploids and $3.50-8.00 \mathrm{cms}$. in the tetraploids. However, both the cytotypes differed in their branching pattern. The diploids were less branched and more or less erect whereas the tetraploids were diffusely branched, with both prostrate and erect branches. The branches were more or less hairy in diploids in contrast to tetraploids where these were smooth.

Leaves: The diploids differed from the tetraploids in the number, size and margin of the leaves. In the former the leaves numbering from 5-20, measured $1.0 \times 0.7 \mathrm{~cm}$. These were shortly petioled and more or less dentate in outline. On the other hand, the tetraploids possessed 10-30 leaves, which measured from $1.5 \times 1.1 \mathrm{cms}$. It was interesting to note that the lower leaves in the tetraploid were petioled with more or less smooth margins in comparison with the upper leaves which were sessile and markedly dentate. The stomata were smaller in diploid $(19.98 \times 13.32 \mu)$ than the tetraploid $(23.31 \times 16.65 \mu)$.

Flowers: Like the vegetative parts, the floral parts also showed a progressive increase in dimensions with the increase in the level of ploidy. The bluish white flowers were smaller in size in the diploid than the tetraploid, and were characterised by pink spots.

Pollen grains: In the diploids, pollen grains were comparatively smaller (14.98 $\times 11.65 \mu)$ in size than tetraploids $(19.98 \times 16.65 \mu)$.

Fruits: Ovoid capsules with persistant calyx $(0.5 \mathrm{~cm}$; diploid; $0.6-0.7 \mathrm{~cm}$, tetraploid) were characteristic of both the cytomorphotypes.

Seeds: Seeds were rectangular in both the cytomorphotypes but varied in size $(120 \times 162-114 \times 150 \mu$ in the diploids and $96 \times 174-120 \times 144 \mu$ in the tetraploids).

The comparative morphological features of the two cytomorphotypes are given in Table 3.

\section{Cytology}

Meiotic studies in the cytomorphotype ' $\mathrm{A}$ ' revealed $\mathrm{n}=7$. The bivalents were more or less uniform in size (about $1.85 \mu$ ) and these underwent normal segregation at anaphases. Fig. 13 shows 7:7 distribution of the chromosomes at A-I. Pollen fertility was measured at $100 \%$.

In the cytomorphotype ' $B$ ' the cytological studies revealed $n=14$. Fig. 14 shows fourteen bivalents which could be classed into two size categories of 7 comparatively larger $(1.80-3.01 \mu)$ and 7 smaller $(1.2-1.7 \mu)$ bivalents. Two of these were nucleolar. Normal meiosis led to $100 \%$ fertile pollen.

Figs. 16-18. Vandellia crustacea. 16, general morphology. A: Diploid $(n=7), B$ : Tetraploid $(\mathrm{n}=14)$. 17, diploid: a, leaves, $\times 8 . \mathrm{b}$, stomata, $\times 810$. c, seeds, $\times 200$. d, pollen grains, $\times 810$. 18, tetraploid: a, leaves, $\times 8$. b, stomata, $\times 810$. c, seeds, $\times 200$. $d$, pollen grains, $\times 810$. 
Table 3. Comparative morphological account of diploid and tetraploid taxa of Vandellia crustacea Benth.

\begin{tabular}{|c|c|c|}
\hline Characters & Diploid 'A' & Tetraploid 'B' \\
\hline Habit and habitat & $\begin{array}{l}\text { Comparatively less branched, } \\
\text { more or less erect taxon, grow- } \\
\text { ing in moist shady places upto } \\
1,500 \mathrm{~m} \text { (Fig. 16a) }\end{array}$ & $\begin{array}{l}\text { Diffusely branched with both pro- } \\
\text { strate and erect branches. Grows } \\
\text { in mat formation in moist and shady } \\
\text { situations within } 300 \mathrm{~m} \text { (Fig. 16b) }\end{array}$ \\
\hline Area of collection & $\begin{array}{l}\text { Kalka, } 500 \mathrm{~m} \\
\text { Mandi (H.P.), } 1,500 \mathrm{~m}\end{array}$ & Chandigarh, $300 \mathrm{~m}$ \\
\hline Flowering period & October-November & October-November \\
\hline Plant size & $3.0-5.0 \mathrm{~cm}$ & $3.5-8.0 \mathrm{~cm}$ \\
\hline Leaves & (Fig. 17a) & (Fig. 18a) \\
\hline Number & $5-20$ & $10-30$ \\
\hline \multicolumn{3}{|l|}{ Size } \\
\hline petiole & $0.3-0.5 \mathrm{~cm}$ & $0.3-0.7 \mathrm{~cm}$ \\
\hline lamina & $1.0 \times 0.7 \mathrm{~cm}$ & $1.5 \times 1.0 \mathrm{~cm}$ \\
\hline $\begin{array}{l}\text { Shape, aspex and } \\
\text { margin }\end{array}$ & $\begin{array}{l}\text { Oblong, more or less dentate } \\
\text { in outline }\end{array}$ & $\begin{array}{l}\text { Oblong, margin of lower leaves } \\
\text { more or less smooth and upper } \\
\text { leaves sessile and markedly dentate }\end{array}$ \\
\hline \multicolumn{3}{|l|}{ Stomata } \\
\hline frequency & $25.0 \%$ & $27.3 \%$ \\
\hline size & $19.98 \times 13.32 \mu$ (Fig. 17b) & $23.31 \times 16.65 \mu$ (Fig. 18b) \\
\hline Inflorescence & $\begin{array}{l}\text { Flowers small, mostly single on } \\
\text { axillary stalk and may form small } \\
\text { racenes at the end of branches. } \\
\text { Flowers bluish white with pink } \\
\text { spots }\end{array}$ & $\begin{array}{l}\text { Flowers small, mostly single on } \\
\text { axillary stalk and forming small } \\
\text { racemes. Flowers bluish white }\end{array}$ \\
\hline Total no. of flowers & $3-8$ & $8-15$ \\
\hline Size of the flower & $0.6 \times 0.3 \mathrm{~cm}$ & $0.9 \times 0.3 \mathrm{~cm}$ \\
\hline Size of the pedicel & $0.6-1.4 \mathrm{~cm}$ & $0.5-1 \mathrm{~cm}$ \\
\hline Size of pollen grain & $14.98 \times 11.65 \mu$ (Fig. 17d) & $19.98 \times 16.65 \mu$ (Fig. 18d) \\
\hline Fruit & $\begin{array}{l}\text { More or less ovoid with } \\
\text { persistant calyx }\end{array}$ & $\begin{array}{l}\text { Oblong to ovoid with persistant } \\
\text { calyx }\end{array}$ \\
\hline Size & $0.45 \mathrm{~cm}$ & $0.5-0.6 \mathrm{~cm}$ \\
\hline Size range of seeds & $120 \times 162-114 \times 150 \mu$ (Fig. 17c) & $96 \times 174-120 \times 144 \mu$ (Fig. $18 c)$ \\
\hline Chromosome no. & $\mathrm{n}=7$ & $\mathrm{n}=14$ \\
\hline
\end{tabular}

The present observations coupled with cytological diversities in literature are indicative of cytomorphological complexity of the species. Both the cytotypes $(\mathrm{n}=7,14)$ reported presently were earlier uninvestigated. Raghavan and Srinivasan (1940) reported $n=21,2 n=42$ from South India (Annamalainagar) for this species while Bhattacharyya (1968) investigated the species as Lindernia crustacea (L.) Mueller from Eastern India and reported the existence of two discordant chromosome numbers $\mathrm{n}=16$ and $\mathrm{n}=21$.

Darlington and Wylie (l.c.) considered $\mathrm{x}=7$ for Vandellia. V. crustacea thus seems to exist at diploid $(n=7)$, tetraploid $(n=14)$, hypertetraploid $(n=16)$ and hexaploid $(\mathrm{n}=21)$ levels. $V$. nummularifolia $(\mathrm{n}=12$ : Gill 1971) is the only other cytologically known species of the genus.

Normal diploid like meiotic behaviour in the tetraploid and two size sets of 7 bivalents each in it suggest its alloploid nature. Its diploid counterpart shows 
equal sized bivalents. Unequal sized chromosomes are also evident in the hexaploid taxon in this species (cf. Raghavan and Srinivasan, 1.c.; p. 45, Fig. 35). The significant morphological differences such as the leaf character, hairyness and branching pattern etc., between the diploids and tetraploids presently investigated, are an added pointer towards the alloploid constitution of the tetraploid taxon.

Much can not be said with certainity about the probable ancestry of the polyploid taxa in V. crustacea. It is, however, worthwhile to point out that the branching pattern and occasionally the leaf shapes in the tetraploid taxon (present observations) are more or less intermediate between $V$. crustacea $(2 \mathrm{x})$ and $V$. multiflora (see Hooker 1.c.). Though, the chromosomal constitution (number and shape) is not known in the latter species, its sympatric distribution with $V$. crustacea $(2 \mathrm{x})$ in N. Indian hills possibly speaks of its being the other parent involved in the evolution of the tetraploid taxon. It may be added that both $V$. crustacea $(2 \mathrm{x})$ and $V$. multiflora differ mainly in their branching habit, leaf and fruit characteristics.

Taking into consideration the present observations together with the earlier records on the species, it seems evident that the different cytotypes of $V$. crustacea complex are distributed from the colder to the warmer climates in India. The pattern of distribution is indicative of the fact that while the diploids prefer colder Northern areas (Common in the hills between $500-1,800 \mathrm{~m}$ ), the tetraploids are met in the less colder areas in the North and East Indian plains, whereas the hexaploids are adapted for the warmer regions extending down into the South India. The different cytotypes in $V$. crustacea thus seem to be geographically isolated and possibly deserve sub-specific ranks atleast. Almost similar state of affairs have earlier been noted in regards to the nature of ploidy and distribution pattern in Veronica anagallis by Khoshoo and Khushu (1966).

\section{Summary}

Cytological studies were carried out in $14 \mathrm{~N}$. Indian taxa. Centranthera hispida $(n=15)$ and Verbascum celsioides $(n=18)$ represent the first chromosome counts for the genus and the species respectively. Two cytomorphotypes with $n=7$ and $\mathrm{n}=14$ in Vandellia crustacea were also unknown earlier. For the remaining taxa one or the other earlier chromosome reports are confirmed. Meiosis was normal in most of the taxa. Secondary associations were observed in Verbascum thapsus and $V$. celsioides. Multiple associations in Antirrhinum majus (2x) represents interchange heterozygosity. Intraspecific aneuploidy in Verbascum thapsus $(2 \mathrm{n}=34,36)$, Antirrhinum orontium $(2 \mathrm{n}=14,16)$, intraspecific polyploidy in Antirrhinum majus $(2 \mathrm{n}=16,32)$, Veronica anagallis $(2 \mathrm{n}=18,36,54)$ and both polyploidy and aneuploidy are evident in Vandellia crustacea $(2 \mathrm{n}=14,28,32,42)$. Origin and evolution of the tetraploid taxon in the last species is discussed.

\section{Acknowledgements}

Our sincere thanks are due to Prof. P. N. Mehra, Head of the Department of Botany, Panjab University, Chandigarh, for the necessary laboratory facilities. 


\section{Literature Cited}

Bamford, R. and Winkles, F. B. 1941. A spontaneous tetraploid snapdragon. J. Heredity 32: 278.

*Beatus, R. 1936. Die Veronica-Gruppe Agrestis der Sektion Alsinebe Griseb., ein Beitrag zum Problem der Artbildung I. Die Zytologie der Gruppe Agrestis. Zeitschr. indukt. Abstamm. u. Vererbungslehre 7 (13): 353-381.

Bhattacharyya, N. K. 1968. Chromosome diversities in Lindernia. Nucleus, Suppl. Vol. 1968: 102-114.

Boryana Stefanova 1974. In IOPB Chromosome number reports. Taxon 23(1): 193-196.

Bose, S. and Panigrahi, U. C. 1969. Effects of colchicine on three varieties of Antirrhinum majus L. Nucleus 12: 159-166.

Darlington, C. D. and Wylie, A. P. 1955. Chromosome Atlas of Flowering Plants. George Allen \& Unwin Ltd., London.

Fedorov, An. A. (editor). 1969. Chromosome Numbers of Flowering Plants. Academy of Sciences of the USSR. V.L. Komarov Botanical Institute.

*Fischer, M. 1969. Einige Chromosomenzahlen aus den Gattungen Veronica, Pseudolysima chion Paederota, Wulfenia and Lagotis. Oesterr. Bot. Zeits. 116: 430-443.

Gadella, Th. W. J. and Kliphuis, E. 1966. Chromosome numbers of flowering plants in the Netherlands II. Proc. Roy. Neth. Acad. Sci. Ser. C. 69: 541-556.

Gill, L. S. 1971. Chromosome number in certain West Himalyaan bicarpellatae species. Bull. Torrey Bot. Club 98: 281.

Håkansson, A. 1926. Zur Zytologie von Celsia und Verbascum. Acta Univ. Lundensis (Lunds Univ. Årsskr.), Avd. 2, 21, 10:1-47.

*Heitz, E. 1926. Der Nachweis der Chromosomen. Vergleichende Studien über ihre Zahl. Grosse und Form im Pflanzenreich. 1.-Zeitschr. Bot., 18 (11-12): 625-681.

- 1927. Chromosomen und Gestalt bei Antirrhinum und verwandten Gattungen. Planta 4, 3: 392-410.

Hooker, J. D. 1885 . The Flora of British India 4: 246-319.

Khoshoo, T. N. and Khushu, C. L. 1966. Biosystematics of Indian plants III. Veronica anagallis complex. Proc. Ind. Acad. Sci. 63: 251.

Kumar, L. S. S. and Abraham, A. 1941. Cytological studies in Indian parasitic plants I. The cytology of Striga. Proc. Ind. Acad. Sci., 14: Ser. B: 509.

${ }^{*}$ Larsen, K. 1967. Cytological studies on Monnina.-Feddes Repertorium, 75(1-2): 43-46.

*Lehmann, E. and Schmitz-Lohner, M. 1954. Entwicklung und Polyploidie in der VeronicaGruppe Agrestis. Zeitschr. indukt. Abstamm. u. Vererbungslehre, 86(1): 1-34.

Löve, A. and D. Löve, 1956. Cytotaxonomical conspectus of Ice landic flora. Acta. Hort. Gotob. 20: 65-290.

Mehra, P. N. and Vasudevan, K. L. 1972. IOPB Chromosome number reports. Taxon 21(2): 342.

- and Vij, S. P. 1972. Cytological studies in the East-Himalayan Orchidaceae-2: Orchideae. Caryologia 25(3): 335-351.

Moore, R. J. (Edit.) 1973. Index to Plant Chromosome Numbers. 1967-1971. Plant Research Institute, Canada Department of Agriculture, Central Experimental Farm, Ottawa, Ontario, KIA OC6, Canada.

Morrison, J. W. and Rajhathy, T. 1960. Frequency of quadrivalents in autotetraploid plants. Nature 187: 528-530.

Mulligan, G. A. 1961. Chromosome numbers of Canadian weeds III. Canda. Jour. Bot. 39: $1057-1066$.

Packer, J. G. 1964. Chromosome numbers and taxonomic notes on Western Canadian and Arctic plants. Canad. Jour. Bot. 42: 473-494.

Propach, H. 1935. Studien über heteroploide Formen von Pollen Mutterzellen der trisomen Anaemica, susca, purpurea, rotunda, candida. Planta 23(3): 349-357.

Rieger, R. 1957. In Homologenpaarung und Meioseablauf bei haploiden Formen von Antirrhinum majus L. Chromosoma 9: 1-38. 
"Rieger, R. 1958. Das Meioseverhalten von Gonotokonten mit abnormen Chromosomenzahlen bei Antirrhinum majus L. Biol. Zbl. 77: 237-244.

Rohweder, H. 1937. Versuch zur Erfassung der mengenmassigen Bedeckung des Darss und Zingst mit polyploiden Pflanzen. Ein Beitrag zur Bedeutung der Polyploidie bei der Eroberung neuer Lebensraume Planta 27(4): 501-549.

${ }^{*}$ Ruttle, M. L. and Nebel, B. R. 1939. Cytogenetic results with colchicine. Biol. Zentral. 59: 79-87.

Sobti, S. N. and Singh, S. D. 1961. A chromosome survey of Indian medicinal plants Part I. Proc. Ind. Acad. Sci. B 54: 138-144.

*Straub, J. 1941. Die Zytologie der haploiden Epilobien und die Phylogenie der Gattung. Biol. Zentralbl. 61(11-12): 573-588.

*Stubbe, H. 1966. Genetk und Zytologie von Antirrhinum L. Sect. Antirrhinum. Vebgustav Fischer Verlag, Jena: 1-421.

Tischler, G. 1937. Die Halligenflora der Nordsee im Lichte cytologischer Forschung. Cytologia, Fujii Jub. Vol.: 162-170.

Vanloon, J. C., Gadella, W. J. and Kliphuis, E. 1971. Cytological studies in some flowering plants from Southern France. Acta. Bot. Neerl. 20: 157-166.

Verma, S. C. and Dhillon, S. S. 1967. In IOPB chromosome number reports XI. Taxon 16: 215-222.

Willis, J. C. 1973. A Dictionary of Flowering Plants and Ferns. Cambridge University Press.

*Wulff, H. D. 1937b. Chromosomenstudien an der schleswigholsteinischen Angiospermen-Flora. 1. Ber. Deutsch. Bot. Ges. 56(7): 247-254.

*Yamashita, K. 1937. Chromosomenzahlen einiger Veronica Arten. Agric. and Hort. (Tokyo) 12(6): 1219-1220.

* Not consulted in original. 